\title{
Unraveling the myth of meritocracy within the context of US higher education
}

\author{
Amy Liu
}

Published online: 25 January 2011

(C) The Author(s) 2011. This article is published with open access at Springerlink.com

\begin{abstract}
Framed by historical and contemporary discussions, this article reviews the principal foundations of meritocracy and uses the public University of California system as a point of departure for examining the connection between meritocracy and higher education within the context of the United States. Through consideration of four dimensions that inform the concept of meritocracy-merit, distributive justice, equality of opportunity, and social mobility - this review examines the underlying tenets of meritocracy to better understand how higher education functions within it. In The Coming of Post-Industrial Society, Daniel Bell (1973) suggested that higher education would become a "defensive necessity." However, if colleges and universities are to serve as instruments for creating and expanding opportunity, then higher education must be more profound than simply being reduced to "defensive necessity," and it is important for researchers to examine more closely the theoretical concerns of meritocracy and the higher education implications.
\end{abstract}

Keywords Access - Admissions - Distributive justice - Equality of opportunity · Higher education $\cdot$ Merit $\cdot$ Meritocracy $\cdot$ Social mobility

\section{Unraveling the myth of meritocracy}

The tremendous expansion of higher education in the United States since World War II and the gravitation towards mass ideals have elevated the important role that higher education plays in social and economic matters (Lucas 2006; Thelin 2004). Variables such as ability, wealth, race and ethnicity, social class, high school context, parental and family involvement, and financial aid have been found to structure and constrain participation in higher education (Geiger 2002; Hossler et al. 1989; McDonough 1997; Teranishi et al. 2004). Bell (1973) once forecasted that in a post-industrial society higher education becomes a "defensive necessity." However, if colleges and universities are to serve as

A. Liu (西)

University of California, Los Angeles, USA

e-mail: amy.liu@ucla.edu 
instruments for creating and expanding opportunity, then higher education must be more profound than simply being reduced to "defensive necessity," and it is important for researchers to examine more closely the underlying theoretical concerns of meritocracy and their higher education implications.

In a meritocracy, social status becomes increasingly dependent upon an individual's level of education (Moore 2004). As Bell (1973) noted, colleges and universities that once reflected the status system of society are now the "gatekeepers" of class position and access to them determines the future stratification of society. Framed by historical and contemporary discussions, I review the principal foundations of meritocracy and use the public University of California system as a point of departure for examining the connection between meritocracy and higher education within the context of the United States. An insightful and nuanced consideration of the issues herein is important because conventional wisdom suggests that meritocracy is a positive system in which society functions. Individuals may believe they are members of the meritocracy because of their level of educational attainment. They are also confident that they are deserving of their reward-be it power, authority, status, and/or wealth-because it has been the product of their own talent and effort. The reality of meritocracy is that it is not so unambiguous. A troubling effect of an uncritical view of meritocracy is that by not acknowledging there are greater structural social inequalities at play, there may be a tendency to view students who do not reach higher levels of educational attainment as having failed on their own terms (Karabel 2005; McNamee and Miller 2004; Young 2001). Therefore, it is necessary to interrogate the notion of meritocracy to better understand how higher education functions within it. I do so through consideration of the dimensions of merit, distributive justice, equality of opportunity, and social mobility, elements that largely inform the concept of meritocracy. As my discussion will draw upon the University of California as an example, I first provide a brief overview of the larger system of public higher education in California.

\section{Higher education in California}

California's public higher education system is one of the largest, most comprehensive, and most distinguished in the United States. Comprised of three segments - the University of California (UC), California State University (CSU), and California Community College (CCC) systems - these publicly supported educational institutions are complemented by hundreds of private colleges and universities. The 10 general UC campuses, $23 \mathrm{CSU}$ campuses, 109 community colleges, and 117 accredited private institutions serve over three million students every year (California Postsecondary Education Commission 2008). ${ }^{1}$

For the past half century, higher education in California has been guided by the state's 1960 Master Plan. Among its many provisions, the Master Plan delineates the roles and responsibilities, as well as articulates general admissions policies for each of the three public segments (Bracco and Callan 2002). In the broadest terms, the UC system houses the research institutions, the CSU system emphasizes teaching, and the CCC system serves as a springboard for transfer to a four-year college or university while also offering

\footnotetext{
1 There are two additional public institutions in California-the Hastings College of Law and the Naval Postgraduate School. The UCs serve more than 208,000 students annually, the CSUs more than 400,000, the CCCs more than 2.5 million, and the private institutions nearly 300,000. The private colleges and universities are accredited by the Western Association of Schools and Colleges (California Postsecondary Education Commission 2008).
} 
vocational and technical education. Each of the sectors has its own governance structure. The UC system operates under shared governance between the Board of Regents, the system-wide president, and the faculty via an academic senate. While these bodies are responsible for establishing university-wide policy, each individual campus also has its own layers of administration and is afforded some level of autonomy for the implementation of policies in practice (Douglass 1998). As my discussion of the following four dimensions proceeds, I will provide additional relevant details of the UC system.

\section{Defining merit}

In undertaking an examination of meritocracy, I begin with its origin. In his seminal 1958 book The Rise of the Meritocracy, Michael Young introduced the word "meritocracy" into the public lexicon. In the book, meritocracy is a pejorative term used to describe a social system that develops based on intelligence testing and educational attainment. In today's vernacular, meritocracy is often referenced as a positive concept that should be aspired to in various aspects of society. The belief that institutions should be governed by people chosen on the basis of merit, perhaps as defined by education and ability, rather than other factors, such as wealth or social class, is one that seems to resonate with the public. However, there are a few factors embedded within the concept of meritocracy that we ought to elucidate.

For a clearer understanding, we also need to consider the basic root of meritocracy. The fundamental idea is that status in society is determined by merit, but what exactly is "merit"? The etymology of merit indicates it is a neutral term worthy of good or bad, praise or punishment (see e.g., Oxford English Dictionary). Merit is intangible, an abstract quality that can only be defined and determined contextually. Wealth, lineage, age, gender, economic efficiency, artistry, technical knowledge, speed, strength, and so forth can be considered merit depending on the circumstances. Sen (2000) suggests that the notion of merit is "underdefined" and "normative" (p. 6). Despite the lack of a concrete definition, in a meritocracy there is generally a positive connotation of merit as something good, something that should be rewarded in a good way. Merit is perhaps most often generally associated with talent, skill, intelligence, ability, and effort. ${ }^{2}$

Within the context of higher education, college and university admissions is one area where the issue of merit and the challenges of defining it are most apparent. Baez (2006) argues that opinions of merit can be rather divisive when the focus concerns access to scarce societal resources, such as entry to highly selective collegiate institutions. From a narrow and restrictive perspective of merit, grade point averages and test scores might be the only driving factors; whereas, a wider and more holistic view might consider special talents, leadership potential, and family background as aspects of merit. Depending on a particular institution's needs and priorities, conceptions of merit may vary. For example, in a study of admissions policies at 17 elite colleges in the United States, Killgore (2009)

\footnotetext{
2 When Young (1958) introduced the term meritocracy, he offered a succinct definition of merit in the form of an equation. He stated that "intelligence and effort together make up merit $(\mathrm{I}+\mathrm{E}=\mathrm{M})$ " (p. 252). Therefore, he claimed the "lazy genius" is not someone who has merit. However, it is possible to dispute that claim. For example, the "lazy genius," despite having a low "E" score, may have an extraordinarily high "I" score such that her overall "M" score far exceeds the person who has average "I" and "E" scores. Furthermore, the equation is rudimentary and using intelligence as a variable is too restrictive. Perhaps a better variable to use is "ability" $(\mathrm{A}+\mathrm{E}=\mathrm{M})$ or "talent" $(\mathrm{T}+\mathrm{E}=\mathrm{M})$.
} 
finds that students' academic and extracurricular accomplishments merely serve as a baseline for admissions consideration. Admissions officers weigh individual talent and effort against their organizational interests and needs, which may include athletic goals, financial stability, and social justice concerns. How administrators define and assess merit can make a significant difference in the composition of the student body.

Articulations of merit generally serve to create and legitimize difference for the purpose of selecting students. Baez (2006) notes that merit is "an institutional construct and that it does not-indeed, it cannot-exist outside the institutions that use it" (p. 997). Karabel (2005) contends that battles over merit reflect larger struggles amongst status-groups. He suggests that the definition of merit "always bears the imprint of the distribution of power in the larger society" (p. 550). Hence, it is not surprising that admissions policies become such politicized points of contention. For example, in the case of a policy such as affirmative action, Rhoads et al. (2005) suggest that the rhetoric and exploits undertaken by proponents and opponents resemble that of a social movement, with each side engaging in its own ideologically and politically rooted collective action. They argue that the conservative push toward derailing affirmative action is every bit as much of a social movement as the liberal fight to uphold it. Essentially, the primary provocation stems from the prefix of meritocracy. Merit is fundamentally subjective and any attempt to demarcate it inevitably renders it vulnerable to critique. ${ }^{3}$

The debate about what constitutes merit is an ongoing one that will confound any conversation about admissions. Changes in policies at the UC system since the mid-1990s exemplify the complexity of deliberations, especially when pertaining to goals of achieving a diverse student body. At issue was the consideration of race and gender in admissions practices, which the UC Board of Regents resolved to eliminate in 1995, a year before California voters mandated the same ban with the passing of Proposition 209 (UCOP 2001a). Since that time and amidst an enduring belief in student diversity, supported by research attesting to its importance (Antonio et al. 2004; Chang 1999; Gurin 1999; Gurin et al. 2002; Milem 2003; Pike and Kuh 2006; Smith et al. 1997), administrators and faculty have sought continuing efforts to capture a multifaceted notion of merit with the implementation of comprehensive and/or holistic admissions review (Bartlett 2006; UCOP 2001b). Most recently, campus leadership again addressed the question of merit with the elimination of certain exam requirements (UCOP 2009). As the UC case illustrates, merit is not and cannot be a static concept. Rather, it requires purposeful reflection that is mindful of the contemporary context.

With all the emphasis on merit, however, it is not surprising that the focus on the suffix of the word has virtually disappeared. According to Lemann (1999), the original idea of an American meritocracy was to create an elite class of civil servants to administer and govern our modern bureaucratic state, much like the French and Japanese civil-service systems. Over time, however, the "-ocracy" aspect of meritoriously selected public servants for civil and government service "evolved into a more general way of distributing opportunity to millions of people, fitting them into places in a highly tracked university system that leads to jobs and professions" (Lemann 1999, p. 344). The idea of meritocracy as a form of governance has seemingly yielded to a structure of distribution, perhaps breeding a greater sense of entitlement among those who believe they have earned whatever rewards they have come to possess (e.g., acceptance to one's college of choice).

\footnotetext{
3 For an extended discussion of affirmative action and challenges to conventional conceptions of merit, see Lapenson (2009).
} 


\section{Distributive justice}

The second dimension to consider concerns the notion that rewards should be given in relation to merit. Such a principle, dating back to Aristotle, is possibly the earliest theory of distributive justice. In an article about quota versus merit systems, Conrad (1976) provides a set of principles for what he considers the essence of a meritocracy (pp. 141-143):

1. Merit should be the sole determinant of an unequal share.

2. The test of merit should be individual talent.

3. The most talented should receive a greater share of society's rewards than the less talented.

4. Everyone should have an equal chance to display his talent or lack thereof (equality of opportunity).

5. Social inequality (deference, income, class standing) is just when it is the outcome of the previously stated principles.

Setting aside the assumptions within these statements and the obvious issues concerning notions of equality and inequality for the moment, what we can ascertain from the above rubric is that a principle of distribution underlies the notion of meritocracy. Notwithstanding the fairness or unfairness of such a system, the key is that rewards in a meritocracy, whether in the form of jobs, power, money, or authority, are distributed on the basis of individual merit. According to Daniels (1978), if we narrow the principle of distribution further to a distribution of income, varying forms of meritocracy can develop dependent upon the desired reward schedule: unbridled meritocracy, desert meritocracy, utilitarian meritocracy, maximin meritocracy, strict egalitarian meritocracy, and socialist meritocracy. ${ }^{4}$ Although these different meritocracies refer to income distribution, we can also consider them in relation to higher education. In this context, the principle of distribution can be tied to the reward of acceptance to a college or university.

Unlike many other countries, the US does not have a ministry of education that engages in the central planning of higher education (Altbach 2001; Eckel and King 2004). Without a centralized mandate for how admissions spaces must be distributed, institutions have the sovereignty to set their own policies and practices. There is a slight caveat with public universities as they may be beholden to state directives, such as coordinated percentage plans for the state's system of higher education, but there is still flexibility in policy implementation at the individual campus level (Horn and Flores 2003). The lack of a central authority offers a level of autonomy for colleges and universities to pursue their own desired admissions reward schedule. Consequently, the decision to accept students on the basis of unbridled, utilitarian, or egalitarian admissions policies demonstrates that the different types of meritocracy Daniels (1978) presents also embody competing ideas of social justice.

Beyond the factor of merit, Sen (2000) argues it is essential that the distribution of social benefits also take into account principles of equality and justice. In simple terms,

\footnotetext{
${ }^{4}$ Daniels (1978) defines these as follows: "unbridled-the reward schedule allows whatever rewards those who attain positions of power and prestige can acquire for themselves; desert-the reward schedule allows rewards proportional to the contribution of the jobs; utilitarian-the reward schedule allows inequalities that act to maximize average or total utility; maximin-the reward schedule allows inequalities that act to maximize the index of primary social goods of those who are worst off; strict egalitarian-no inequalities in reward are allowed; socialist-the reward schedule allows no inequalities in the satisfaction of basic needs" (pp. 218-219).
} 
meritocracy places primary importance on merit and talent, but at its core, meritocracy is also a reward schedule with larger social ramifications. Philosophers reasoning the morality of distributive justice offer contrasting ideas about what one "deserves" or is "entitled to." Sandel (1998) parses the competing views of John Rawls and Robert Nozick, highlighting Rawls' difference principle and Nozick's entitlement theory. In essence, Rawls holds a more egalitarian perspective of distributive justice, defending social and economic inequalities only when they are to the benefit of society's most disadvantaged members. This argument appears to align with Daniels' (1978) definition of maximin meritocracy. Nozick, instead, embraces a more libertarian stand, contending that any resulting reward differentials are acceptable, independent of others' situations (e.g., unbridled meritocracy). These are pertinent deliberations to consider with regard to the role that social institutions, such as colleges and universities, occupy in a meritocracy. For example, should students be rewarded with admissions offers on the basis of their individual talents and effort, or should they be granted admission because they will serve a greater common social goal (e.g., increasing the number of female scientists)? In either scenario, which may or may not be mutually exclusive, the discussion concerns the best or most desired approach for the allocation of limited spaces.

In a meritocracy, the admissions process is just one of the ways in which colleges and universities play a significant role in the distribution of rewards. Tasked with reviewing applications and extending offers to attend their institutions, admissions officers are the key arbiters to whether or not individuals receive the education they believe they are entitled to or deserve. In the US mass higher education system, an opportunity exists for nearly every student who wishes to pursue higher education. Despite there being tremendous institutional diversity, the system is also highly stratified (Hurtado 2003), ${ }^{5}$ and the most selective institutions ought to be the most cognizant of distributive justice. It is also equally, if not more, imperative that public institutions be attentive to distributive justice given their social contract to constituents (Douglass 2007). The UC system's varying admissions eligibility contexts, comprehensive review procedures, and responsibility to the mandates of the California Master Plan serve as an example of the multiple considerations admissions personnel must undertake. It also reflects the balance they must strike in their assessment of students amidst numeric and public mission concerns (UC 2009; UCOP 2007, 2009). The outcomes of admissions policies, however, do not always coalesce with certain stated intents of distributive justice. Douglass (2007) finds that the UC's comprehensive review policy, established to guard against the admissions decline of underrepresented students in light of state legislation, was only marginally successful. It also did not help stem the growing disparity between the state's racial and ethnic composition of high school graduates and university enrollment.

In another example, Stevens' (2007) in-depth examination of admissions at one elite college also demonstrates the complexity of factors that those charged with making rewards decisions must weigh. The process can be likened to a continuum that moves from "coarse sorts," such as systematic preferences based upon organizational interests, to "fine distinctions" wherein admissions officers engage in highly individualized considerations of applicants (p. 187). In order to achieve the latter, the officers are drawn into what Stevens calls "evaluative storytelling" as a means of distinguishing students from one another (p. 186). Ultimately, their efforts result in decisions that most likely align with Conrad's

\footnotetext{
5 The stratification happens along dimensions of admissions selectivity; mission such as research institution, comprehensive education, or vocational training; public versus private domain; and for-profit versus nonprofit intent.
} 
(1976) reasoning. Though admissions personnel do not perform their responsibilities without the best of intentions in relation to the institution or to the student, Stevens argues that "individualized consideration does little to mitigate class privilege, and, indeed, exaggerates it" (p. 190). Such a contention would seem to challenge equality of opportunity, which is a central tenet of meritocracy.

\section{Equality of opportunity}

The third dimension examines an underlying imperative in a system of distribution based on merit-equality of opportunity. That is, individuals must be given an equal chance to demonstrate their talent in the competition for rewards. In the equality of opportunity discourse, one line of reasoning is what Sandel (1998) and Roemer (2000) deem "natural liberty" or the "nondiscrimination view," respectively (p. 67 and p. 18). The idea is that if anyone who has the relevant qualifications is allowed to participate, then everyone has an equal opportunity to compete for rewards. Another perspective suggests a need to level the playing field, allowing for "pervasive social provision to correct for all manner of disadvantage" (Roemer 2000, p. 18). Sandel (1998) views this as "liberal equality," wherein the goal is to achieve a "fair meritocracy', in which social and cultural inequalities are mitigated by equal educational opportunities, certain redistributive policies, and other social reforms" (p. 68). Norman (1987) reminds us that equality of opportunity is essentially an "equal opportunity to be unequal" (p. 103). Indeed, a meritocracy is not generally understood to be strictly egalitarian as it tends to be driven by an unequal distribution of rewards.

At the UC system, the various paths for undergraduate admissions appear to be attempts toward establishing a baseline equality of opportunity. As long as students who are California residents meet the requirements of one the established admissions contexts, including eligibility in the statewide context, eligibility in the local context, and eligibility by examination alone, then there is an equal opportunity to compete for guaranteed admission to one of the system's nine undergraduate campuses (UC 2009). Requirements at the statewide level include completion of specific coursework and college admissions tests, earning the compulsory grade point average and test scores, respectively. In the local context, students at participating California high schools must rank in the top four percent of their graduating class. Those opting for the exam route must achieve specified high scores on their college admissions tests. Although students are offered definite admission to the UC system, they are not guaranteed to be admitted to the campus of their choice. Similar to the institutional hierarchy of US higher education (Hurtado 2003), some UC campuses have higher selectivity rates and are considered more prestigious than others.

While the UC scenario may appear to be a straightforward example of equality of opportunity, a number of issues concerning access to higher education reveal the inconsistencies of what exactly equal opportunity entails. In the US, this is perhaps most salient with regard to competition for admission to the colleges and universities that reside at the upper strata of the institutional hierarchy. Two key questions inform the discussion: Was there equality of opportunity for achieving the relevant qualifications for admissions? Once eligibility is established, does equality of opportunity continue as the competition ensues?

The first question underscores the weakness of the natural liberty perspective that possession of relevant qualifications is sufficient for establishing an equal opportunity to compete for rewards. Research investigating college access identifies multiple factors including, but not limited to, high school context, role of college counseling, and family 
involvement, that can foster or deter the acquisition of necessary qualifications (Espenshade et al. 2005; McDonough 1997, 2005; Perna et al. 2008; Tierney and Auerbach 2005; Venezia and Kirst 2005). These findings demonstrate that inequitable environments abound and cannot easily be remedied. For example, adequate college counseling in the secondary sector, particularly at low-socioeconomic status public schools, is often lacking due to inordinately high student-to-counselor ratios, the multitude of counseling priorities, and fiscal constraints. These types of structural limitations preclude the chance of equal opportunity for college preparation when compared to private high schools that employ dedicated college admissions counselors who can provide one-on-one guidance to students (McDonough 2005). The availability of more rigorous college preparatory curricula at better-resourced schools is another example of differential opportunities that diminishes the likelihood there can ever be parity of prospects for college attendance (Venezia and Kirst 2005).

Students for whom a college-going culture is ingrained into their high school lives are readily familiar with the norms and values of the admissions process. They also have the support structures needed to facilitate the transition to college. For students who are not as aware of what the process entails, the pursuit of higher education is a more difficult, though still attainable endeavor. College outreach programs are examples of strategies implemented to help establish a college-bound culture in order to mitigate the inequality of opportunity that exists for some students prior to attaining pertinent admissions qualifications (Perna and Swail 2001). The program providers include state and federal governments, private foundations, and individual colleges and universities. Though recent research suggests that the magnitude of these programs' impact is mixed (Domina 2009; Schultz and Mueller 2006), at the very least, their intention is to account for social and cultural disadvantages, thereby embracing the goals of liberal equality.

Although the purpose of outreach programs is to provide a means for leveling the playing field in the achievement of relevant qualifications, equality of opportunity is again challenged once eligibility is established and the contest for admissions rewards ensues. With national news outlets visibly feeding the immense spectre of competition at highly selective schools (Arenson 2008; Tyre 2008), a whole industry has developed that persists in undermining equality of opportunity. An entrepreneurial admissions sector comprised of commercial enterprises aimed at helping students increase their odds of admission exists to capitalize on the inevitably unequal distribution of limited spaces (Liu 2011; McDonough et al. 2000). Students seeking to leverage their own opportunities in order to gain an edge over their peers often procure two of the sector's main activities: standardized test preparation (test prep) and private college counseling. These students tend to be from higher socioeconomic backgrounds and have the financial means and knowledge for securing these additional tactics (Buchmann et al. 2006; McDonough et al. 1997). By accruing greater advantage over students who have not had similar options, the benefits of improved examination scores and insider knowledge of the admissions process from private counselors can translate to a higher likelihood of an offer of admission. Park and Eagan (2011) find that being a beneficiary of private college counseling is the strongest predictor of being admitted to a school through an early admissions program, which Avery et al. (2004) note is a system that "may magnify the advantages of the wealthy and well-connected" (p. 257). It seems that while equality of opportunity is generally a strong basis for the widespread acceptance of meritocracy as a valued system, it appears to be an elusive principle in the pursuit of higher education. 


\section{Social mobility}

Although it seems doubtful there can ever be true equality of opportunity for access to higher education, a final dimension of meritocracy to consider is how higher education might serve as the mechanism for providing an equal opportunity for social mobility. According to Moore (2004), a meritocratic system allows people to "achieve social status by virtue of their actual abilities and contributions rather than having it merely 'ascribed' by accident of birth" (p. 39). Driven largely by education, social mobility becomes reality as class origin is no longer a roadblock to a better life. Husén (1974) states that in an open society, "the individual is the prime mover, and should be free to move ahead and to realize his potentialities as much as he desires" (p. 110). The opportunity for social mobility can be a powerful motivator for success. To the extent that individuals are not hindered by anything other than their own will and aspiration, the attainability of higher social status and wealth can be incentives for educational achievement. Aptitude and talent will undoubtedly vary and not everyone will be capable of climbing the social ladder, but assuming that higher education is a means by which meritorious traits can be cultivated or signaled, one's success in life is ostensibly limitless.

Although meritocracy enables social mobility, it also upholds the status quo of a stratified society. Bell (1973) writes, "In social fact, the meritocracy is thus the displacement of one principle of stratification by another, of achievement for ascription" (p. 426). Husén (1974) notes more specifically that "educated ability is the democratic substitute for inherited status and wealth" (p. 8). Meritocracy does not aim to create a classless society, but it legitimizes the given hierarchical structure and empowers people to be socially re-classified. Social class assignments are not absolute, and the resulting social order is seemingly more justifiable if one's higher status is earned. In this case, higher education can be viewed as concurrently promoting social mobility and legitimizing stratification. Entwistle (1977) suggests, "If élites are sociologically inevitable then those recruited from the highly intelligent and diligent products of the educational system seem preferable to those derived from birth or wealth" (p. 10). Lemann (1999) concurs, noting that it is accepted as a "sacred first principle that our society rewards those who deserve and have earned advancement rather than distributing reward by fiat in some way that involves circumstances of birth" (p. 343). If we acknowledge the proposition that stratification can be a means of maintaining societal stability and that social inequality is an unavoidable consequence of a complex society, then the argument is that it is more acceptable for educational merit to be the arbiter of social status and to serve as an enabler for social mobility.

The California Master Plan is a prime example of a coordinated design that promotes social mobility, while it also upholds stratification and differential status. By distinguishing the missions of the three tiers of institutions in the California system-UC, CSU, and community colleges - the intent was to create a system that encouraged collaboration and limited competition. The Master Plan also established an admissions principle of universal access and choice, delegating UC to select its freshmen students from the top one-eighth $(12.5 \%)$ of the high school graduating class and CSU from the top one-third (33.3\%). The community colleges were to admit any student capable of benefiting from instruction (UCOP 2007). One of the most important provisions for collaboration and social mobility was the transfer function whereby students, particularly from low socioeconomic backgrounds, who began studies at the community colleges would have the opportunity to transfer to a four-year institution and earn a baccalaureate degree. 
Educational attainment is not always the most appropriate determination of merit, but in a meritocracy it serves as a signaling tool and having a college degree can greatly improve the chances of moving up the income ladder (Baum and Ma 2007; Haskins 2008). Generally, for all community colleges in the US, the transfer potential has been touted for its goals of access, equal opportunity, and mobility. However, research has shown that this tier of higher education can have the effect of stifling and diverting educational aspirations (Brint and Karabel 1989; Dougherty 1994). For example, Long and Kurlaender (2009) find that within 9 years, students who began studies at community colleges are $14.5 \%$ less likely to complete a baccalaureate degree compared to those who entered four-year institutions directly. Additionally, Park and Pascarella (2010) find that compared to fouryear students, those attending community colleges had lower educational and occupational plans. They note, however, that their findings are modest and conditional; the lowered expectations are stronger for women and those with higher tested cognitive ability, suggesting a possible "cooling-out" function (Clark 1960). Community college students are also less likely to transfer to elite colleges and universities, institutions that can offer greater opportunities for social mobility. Dowd et al. (2008) clearly show that "elite colleges are not using transfer admissions to reduce the inequitable socioeconomic composition of their student bodies, despite the disproportionate enrollment and availability of low-income students in community colleges" (pp. 460-461).

Understanding the mobility intents and outcomes at community colleges is important given their potential as a stepping stone to a baccalaureate education (Dowd 2003), but as a college degree becomes the norm (Goyette 2008), the traditional four-year degree also becomes a mere pathway for continued educational mobility. Studies show that college quality and college major can impact the level of earnings as well as the pursuit of graduate education (Eide et al. 1998; Monks 2000; Thomas and Zhang 2005; Wolniak et al. 2008; Zhang 2005a,b). Increased earnings and higher levels of education may be indicators of mobility, but the question to ponder is: Does having a university degree, especially from an elite institution, warrant greater rewards, particularly at the expense of those who may not have had similar educational opportunities? Bell (1973) suggests that a meritocracy predicated on educational attainment creates "a 'credentials society' in which certification of achievement-through college degree, the professional examination, the licensebecomes a condition of higher employment" (p. 414). Collins (2002) views credentials from an inflationary perspective and states that "most degrees have little substantive value in themselves; they are bureaucratic markers channelling access to the point at which they are cashed in, and guaranteeing nothing about their value at the point at which they are cashed" (p. 24). He goes on to suggest that credentialism is supply-driven given that rising educational requirements are not a consequence of increasing functional job requirements. Although there may be other theories to explain the relationship between educational credentials and socioeconomic attainment (Bills 2003), the more important point to bear in mind is that in a meritocracy, credentials may not be an equitable signifier of achievement.

\section{Meritocracy in context}

The perception of the US system of higher education as a meritocratic one that also holds firm to ideals of universal access is a powerful impression that serves to reify higher education's significance in a meritocracy. Owing to the thousands of institutions in the system, an opportunity exists for every student who wishes to pursue higher education. However, the differentiated roles of mass and elite institutions produces a highly 
hierarchical system with the small number of research universities at the pinnacle of the pyramid and the larger number of community colleges forming the base. Existing in between are institutions that to varying degrees foster the elite or mass purpose, all of which enable the sorting and selection of students into colleges or universities best suited to students' abilities and preferences (Hurtado 2003). The belief in meritocratic ideals and the democratization of access, however, is supposed to empower mobility between institutional types (Trow 2001). Karabel (2005) argues that a prominent reason for the symbiosis of meritocracy and higher education is because "the legitimacy of the American social order depended in good part on the public's confidence that the pathways to success provided by the nation's leading universities were open to individuals from all walks of life" (p. 543). However, such optimism is misguided as he demonstrates that access to these institutions has been enshrouded in a history of battles between status-groups.

The rhetoric of meritocracy can be persuasive and it holds much allure, but it is also a myth that serves to detract from the work of social justice. McNamee and Miller (2004) suggest that American higher education "is not governed by strict principles of meritocracy, but instead, reflects, legitimizes, and reproduces class inequalities" (p. 112). Criticisms concerning preferences for children of alumni (legacies) or powerful and wealthy donors diminish the perception that institutions are meritocratic (Golden 2006). Early admissions policies that disproportionately "advantage the already advantaged" also serve to undermine the ideals of meritocracy (Karabel 2005, p. 551). Even programs that have been implemented to mitigate social disadvantages and foster liberal equality, such as affirmative action, can be spun in ways that suggest the policy is either antithetical or imperative to meritocracy. Opponents of affirmative action claim that considerations of racial diversity lower academic standards and therefore cannot be any kind of reflection of merit. Supporters argue that affirmative action levels the playing field for historically disadvantaged students and therefore is critical to ensuring equality of opportunity. Indeed, the politics of admissions, especially for scarce spaces, yields many passionate points of view. A commitment to social justice therefore requires that we carefully consider all the underlying facets of meritocracy, including the definition of merit, distributive justice, equal opportunity, and social mobility.

Karabel (2005) and Lemann (1999) both note that Young's (1958) dystopic vision of a meritocratic society stemmed from his belief that widespread acceptance of meritocracy would extinguish the cause of social justice. Meritocracy is a justification for inequality, which did not sit well with Young's egalitarian views. In 1958, Young wrote a social science fable to capture what he believed would happen to a society enthralled with meritocracy. Over 40 years later in a 2001 Guardian newspaper article, Young wrote that much of what he predicted had come about, and he was particularly wary about the casual overuse of the word meritocracy, especially by politicians. In the 2001 article, the late Young claimed that meritocracy breeds "insufferably smug" meritocrats who feel entitled to whatever rewards "they arrogate to themselves" because they believe they advanced on their own merit and achievement. The meritorious become so self-assured as to "actually believe they have morality on their side." The others are left "morally naked" having been judged as not having merit and having been "looked down on so woundingly by people who have done well for themselves." Left without a voice, they become "disengaged" and "disaffected" citizens. General inequality becomes more "grievous," yet accepted as time progresses and the cause of social justice dwindles. This may sound extreme, but if our recent history of lower taxes for the wealthy, widening income inequality, and skyrocketing salaries and bonuses for top corporate executives despite their gross abuses of power 
are potential indications of meritocracy run amok, then Young's views are perhaps not quite so polemic.

In the present day it seems largely taken for granted that meritocracy is a positive and preferred system in which society functions. As a principle of distribution, one might find it agreeable that those with greater skill should be more highly compensated. After all, why should not the most talented enjoy greater successes and rewards, especially if there was an equal opportunity to earn them? This may sound like a harmless ideal to hold onto, but at best it is naïve. It also contributes to the tension between what Sen (2000) argues is "the inclination to see merit in fixed and absolute terms and the ultimate instrumental character of merit" (p. 5). Furthermore, the idea of equality of opportunity is far more elusive than it would appear and requires that we duly consider how power and privilege are often embedded into opportunity structures. One of the strongest arguments for meritocracy is that it subverts factors of heredity and substitutes achievement for ascription. This proposition is an overreaching one as Bell (1973) so simply notes, "There can never be a pure meritocracy because, invariably, high-status parents will seek to pass on their positions either through the use of influence or simply by the cultural advantages their children would possess. Thus, after one generation a meritocracy simply becomes an enclaved class" (p. 427).

As I believe I have shown through the arguments presented, we should exercise caution in extolling the virtues of meritocracy. Given that higher education can play a substantial role in the adjudication of future jobs and material rewards, as well as transform or reproduce the social structure, more thoughtful reflection of all the facets of meritocracy is essential in order to better understand what its underlying foundations entail within the context of higher education. This ensures that higher education is not simplified into mere "defensive necessity" and that true commitment to equality of educational opportunity remains paramount. Most importantly, we cannot allow the myth of meritocracy to overshadow the cause of social justice for those who have faced discrimination and have systemically accumulated disadvantages.

Open Access This article is distributed under the terms of the Creative Commons Attribution Noncommercial License which permits any noncommercial use, distribution, and reproduction in any medium, provided the original author(s) and source are credited.

\section{References}

Altbach, P. G. (2001). The American academic model in comparative perspective. In P. G. Altbach, P. J. Gumport, \& D. B. Johnstone (Eds.), In defense of American higher education (pp. 11-37). Baltimore, MD: The Johns Hopkins University Press.

Antonio, A. L., Chang, M. J., Hakuta, K., Kenny, D. A., Levin, S., \& Milem, J. F. (2004). Effects of racial diversity on complex thinking in college students. Psychological Science, 15, 507-510.

Arenson, K. W. (2008, January 17). Applications to colleges are breaking records [Electronic Version]. The New York Times. Retrieved December 7, 2008, from http://www.nytimes.com/2008/01/17/ education/17admissions.html?_r=1.

Avery, C., Fairbanks, A., \& Zeckhauser, R. (2004). The early admissions game: Joining the elite. Cambridge, MA: Harvard University Press.

Baez, B. (2006). Merit and difference. Teachers College Record, 108(6), 996-1016.

Bartlett, L. (2006, September 28). UCLA adopts holistic approach to reviewing freshman applications. Retrieved August 4, 2010, from http://www.universityofcalifornia.edu/news/article/8541.

Baum, S., \& Ma, J. (2007). Education pays: The benefits of higher education for individuals and society. Washington, DC: College Board.

Bell, D. (1973). The coming of post-industrial society. New York: Basic Books, Inc. 
Bills, D. B. (2003). Credentials, signals, and screens: Explaining the relationship between schooling and job assignment. Review of Educational Research, 73(4), 441-469.

Bracco, K. R., \& Callan, P. M. (2002). Competition and collaboration in California higher education. San Jose, CA: The National Center for Public Policy and Higher Education.

Brint, S., \& Karabel, J. (1989). The diverted dream: Community colleges and the promise of educational opportunity in America, 1900-1985. New York: Oxford University Press.

Buchmann, C., Roscigno, V. J., \& Condron, D. J. (2006, August). The myth of meritocracy? SAT preparation, college enrollment, class and race in the United States. Paper presented at the annual meeting of the American Sociological Association, Montréal, Quebec, Canada.

California Postsecondary Education Commission. (2008). California colleges and universities, 2008: A guide to California's degree-granting institutions and degree, certificate, and credential programs. Sacramento, CA: California Postsecondary Education Commission.

Chang, M. J. (1999). Does racial diversity matter? The educational impact of a racially diverse undergraduate population. Journal of College Student Development, 75, 105-126.

Clark, B. R. (1960). The "cooling-out" function in higher education. The American Journal of Sociology, 65(6), 569-576.

Collins, R. (2002). Credential inflation and the future of universities. In S. Brint (Ed.), The future of the city of intellect: The changing American university (pp. 23-46). Stanford, CA: Stanford University Press.

Conrad, T. R. (1976). The debate about quota systems: An analysis. American Journal of Political Science, 20(1), 135-149.

Daniels, N. (1978). Merit and meritocracy. Philosophy \& Public Affairs, 7(3), 206-223.

Domina, T. (2009). What works in college outreach: Assessing targeted and schoolwide interventions for disadvantaged students. Educational Evaluation and Policy Analysis, 31(2), 127-152.

Dougherty, K. J. (1994). The contradictory college: The conflicting origins, impacts, and futures of the community college. Albany: State University of New York Press.

Douglass, J. A. (1998). Shared governance at the University of California: An historical review. Center for Studies in Higher Education, UC Berkeley. Retrieved August 4, 2010, from http://www.escholarship. org/uc/item/07q345d0.

Douglass, J. A. (2007). The conditions for admission: Access, equity, and the social contract of public universities. Palo Alto, CA: Stanford University Press.

Dowd, A. C. (2003). From access to outcome equity: Revitalizing the democratic mission of the community college. Annals of the American Academy of Political and Social Science, 586(March), 92-119.

Dowd, A. C., Cheslock, J. J., \& Melguizo, T. (2008). Transfer access from community colleges and the distribution of elite higher education. The Journal of Higher Education, 79(4), 442-472.

Eckel, P. D., \& King, J. E. (2004). An overview of higher education in the United States: Diversity, access, and the role of the marketplace. Retrieved January 11, 2007, from http://www.acenet.edu/book store/pdf/2004_higher_ed_overview.pdf.

Eide, E., Brewer, D. J., \& Ehrenberg, R. G. (1998). Does it pay to attend an elite private college? Evidence on the effects of undergraduate college quality on graduate school attendance. Economics of Education Review, 17(4), 371-376.

Entwistle, H. (1977). Class, culture and education. London: Methuen.

Espenshade, T. J., Hale, L. E., \& Chung, C. Y. (2005). The frog pond revisited: High school academic context, class rank, and elite college admission. Sociology of Education, 78, 269-293.

Geiger, R. L. (2002). The competition for high-ability students: Universities in a key marketplace. In S. Brint (Ed.), The future of the city of knowledge: The changing American university (pp. 82-106). Stanford, CA: Stanford University Press.

Golden, D. (2006). The price of admission: How America's ruling class buys its way into elite colleges-and who gets left outside the gates. New York: Crown Publishers.

Goyette, K. A. (2008). College for some to college for all: Social background, occupational expectations, and educational expectations over time. Social Science Research, 37(2), 461-484.

Gurin, P. (1999). Expert report of Patricia Gurin. The compelling need for diversity in higher education. Gratz et al. v. Bollinger, et al., No. $97-75321$ (E.D. Mich.) Grutter et al. v. Bollinger, et al., No. 9775928 (E.D. Mich.). Ann Arbor: University of Michigan.

Gurin, P., Dey, E. L., Hurtado, S., \& Gurin, G. (2002). Diversity and higher education: Theory and impact on educational outcomes. Harvard Education Review, 72(3), 330-366.

Haskins, R. (2008). Education and economic mobility. In J. B. Isaacs, I. V. Sawhill, \& R. Haskins (Eds.), Getting ahead or losing ground: Economic mobility in America (pp. 91-104). Washington, DC: The Brookings Institution.

Horn, C. L., \& Flores, S. M. (2003). Percent plans in college admissions: A comparative analysis of three states' experiences. Cambridge, MA: The Civil Rights Project Harvard University. 
Hossler, D., Braxton, J., \& Coopersmith, G. (1989). Understanding student college choice. In J. C. Smart (Ed.), Higher education: Handbook of theory and research (Vol. V, pp. 231-288). New York: Agathon Press.

Hurtado, S. (2003). Institutional diversity in American higher education. In S. R. Komives, D. B. Woodard Jr, \& Associates (Eds.), Student services: A handbook for the profession (4th ed., pp. 23-44). San Francisco, CA: Jossey-Bass.

Husén, T. (1974). Talent, equality and meritocracy: Availability and utilization of talent. The Hague, Netherlands: Martinus Nijhoff.

Karabel, J. (2005). The chosen: The hidden history of admission and exclusion at Harvard, Yale, and Princeton. New York: Houghton Mifflin Company.

Killgore, L. (2009). Merit and competition in selective college admissions. The Review of Higher Education, 32(4), 469-488.

Lapenson, B. P. (2009). Affirmative action and the meanings of merit. New York: University Press of America, Inc.

Lemann, N. (1999). The big test: The secret history of the American meritocracy. New York: Farrar, Straus and Giroux.

Liu, A. (2011). The admission industrial complex: Examining the entrepreneurial impact on college access. Journal of College Admission, 2010(Winter 2011), 8-19.

Long, B. T., \& Kurlaender, M. (2009). Do community colleges provide a viable pathway to a baccalaureate degree? Educational Evaluation and Policy Analysis, 31(1), 30-53.

Lucas, C. J. (2006). American higher education: A history (2nd ed.). New York: Palgrave Macmillan.

McDonough, P. M. (1997). Choosing colleges: How social class and schools structure opportunity. Albany, NY: State University of New York Press.

McDonough, P. M. (2005). Counseling matters: Knowledge, assistance, and organizational commitment in college preparation. In W. G. Tierney, Z. B. Corwin, \& J. E. Colyar (Eds.), Preparing for college: Nine elements of effective outreach (pp. 69-87). Albany, NY: State University of New York Press.

McDonough, P. M., Korn, J., \& Yamasaki, E. (1997). Access, equity, and the privatization of college counseling. The Review of Higher Education, 20(3), 297-317.

McDonough, P. M., Ventresca, M. J., \& Outcalt, C. (2000). Field of dreams: Organization field approaches to understanding the transformation of college access, 1965-1995. In J. C. Smart \& W. G. Tierney (Eds.), Higher education: Handbook of theory and research (Vol. XV, pp. 371-405). New York: Agathon Press.

McNamee, S. J., \& Miller, R. K., Jr. (2004). The meritocracy myth. New York: Rowman \& Littlefield Publishers, Inc.

Milem, J. F. (2003). The educational benefits of diversity: Evidence from multiple sectors. In M. J. Chang, D. Witt, J. Jones, \& K. Hakuta (Eds.), Compelling interest: Examining the evidence on racial dynamics in colleges and universities (pp. 126-169). Stanford, CA: Stanford University Press.

Monks, J. (2000). The returns to individual and college characteristics: Evidence from the National Longitudinal Survey of Youth. Economics of Education Review, 19(3), 279-289.

Moore, R. (2004). Education and society: Issues and explanations in the sociology of education. Cambridge, England: Polity Press.

Norman, R. (1987). Free and equal. Oxford, UK: Oxford University Press.

Park, J. J., \& Eagan Jr., M. K. (2011). Who goes early?: A multi-level analysis of enrolling via early action and early decision admissions. Teachers College Record, 113(11).

Park, S., \& Pascarella, E. T. (2010). Community college attendance and socioeconomic plans. Community College Journal of Research and Practice, 34(9), 700-716.

Perna, L. W., Rowan-Kenyon, H. T., Thomas, S. L., Bell, A., Anderson, R., \& Li, C. (2008). The role of college counseling in shaping college opportunity: Variations across high schools. The Review of Higher Education, 31(2), 131-159.

Perna, L. W., \& Swail, W. S. (2001). Pre-college outreach and early intervention. Thought \& Action, 17(1), 99-110.

Pike, G. R., \& Kuh, G. D. (2006). Relationships among structural diversity, informal peer interaction, and perception of the campus environment. The Review of Higher Education, 29(4), 425-450.

Rhoads, R. A., Saenz, V., \& Carducci, R. (2005). Higher education reform as a social movement: The case of affirmative action. The Review of Higher Education, 28(2), 191-220.

Roemer, J. E. (2000). Equality of opportunity. In K. Arrow, S. Bowles, \& S. Durlauf (Eds.), Meritocracy and economic inequality (pp. 17-32). Princeton, NJ: Princeton University Press.

Sandel, M. J. (1998). Liberalism and the limits of justice (2nd ed.). Cambridge, UK: Cambridge University Press. 
Schultz, J. L., \& Mueller, D. (2006). Effectiveness of programs to improve postsecondary education enrollment and success of underrepresented youth: A literature review. St. Paul, MN: Wilder Research.

Sen, A. (2000). Merit and justice. In K. Arrow, S. Bowles, \& S. Durlauf (Eds.), Meritocracy and economic inequality (pp. 5-16). Princeton, NJ: Princeton University Press.

Smith, D. G., et al. (1997). Diversity works: The emerging picture of how students benefit. Washington, DC: Association of American Colleges and Universities.

Stevens, M. L. (2007). Creating a class: College admissions and the education of elites. Cambridge, MA: Harvard University Press.

Teranishi, R. T., Ceja, M., Antonio, A. L., Allen, W. R., \& McDonough, P. (2004). The college-choice process for Asian Pacific Americans: Ethnicity and socioeconomic class in context. The Review of Higher Education, 27(4), 527-551.

Thelin, J. R. (2004). A history of American higher education. Baltimore, MD: The Johns Hopkins University Press.

Thomas, S. L., \& Zhang, L. (2005). Post-baccalaureate wage growth within 4 years of graduation: The effects of college quality and college major. Research in Higher Education, 46(4), 437-459.

Tierney, W. G., \& Auerbach, S. (2005). Toward developing an untapped resource: The role of families in college preparation. In W. G. Tierney, Z. B. Corwin, \& J. E. Colyar (Eds.), Preparing for college: Nine elements of effective outreach (pp. 29-48). Albany, NY: State University of New York Press.

Trow, M. (2001). From mass higher education to universal access: The American advantage. In P. G. Altbach, P. J. Gumport, \& D. B. Johnstone (Eds.), In defense of American higher education (pp. 110-143). Baltimore, MD: The Johns Hopkins University Press.

Tyre, P. (2008, January 3). Getting in gets harder [Electronic Version]. Newsweek. Retrieved December 7, 2008, from http://www.newsweek.com/id/83159.

UC University of California (2009). Freshman admission. Retrieved August 4, 2010, from http://www. universityofcalifornia.edu/admissions/undergrad_adm/paths_to_adm/freshman.html.

UCOP University of California Office of the President (2001a, May). SP-1 and SP-2. Retrieved August 4, 2010, from http://www.ucop.edu/ucophome/commserv/factsheets/sp1and2.pdf.

UCOP University of California Office of the President (2001b, November). Comprehensive review. Retrieved August 4, 2010, from http://www.ucop.edu/news/factsheets/2001/comprev.pdf.

UCOP University of California Office of the President (2007, January). California master plan for higher education: Major features. Retrieved August 4, 2010, from http://ucfuture.universityofcalifornia.edu/ documents/ca_masterplan_summary.pdf.

UCOP University of California Office of the President (2009, February 5). UC regents adopt changes to freshman eligibility. Retrieved August 4, 2010, from http://www.universityofcalifornia.edu/news/ eligibilitychanges/documents/eligibility_factsheet.pdf.

Venezia, A., \& Kirst, M. W. (2005). Inequitable opportunities: How current education systems and policies undermine the chances for student persistence and success in college. Educational Policy, 19(2), 283-307.

Wolniak, G. C., Seifert, T. A., Reed, E. J., \& Pascarella, E. T. (2008). College majors and social mobility. Research in Social Stratification and Mobility, 26(2), 123-139.

Young, M. (1958). The rise of the meritocracy. London: Thames and Hudson.

Young, M. (2001, June 29). Down with meritocracy. The Guardian. Retrieved December 6, 2004, from http://www.guardian.co.uk/comment/story/051420700.html.

Zhang, L. (2005a). Advance to graduate education: The effect of college quality and undergraduate majors. The Review of Higher Education, 28(3), 313-338.

Zhang, L. (2005b). Do measures of college quality matter? The effect of college quality on graduates' earnings. The Review of Higher Education, 28(4), 571-596. 